\title{
Knowledge, attitude and practice of contraception among women attending a tertiary care hospital in India
}

\author{
Sunita TH*, Rathnamala M Desai
}

Department Obstetrics and Gynecology, SDM College of Medical Sciences \& Hospital, Sattur, Dharwad, India

Received: 19 February 2013

Accepted: 22 March 2013

\author{
*Correspondence: \\ Dr. Sunitha TH, \\ E-mail: srposdm@yahoo.com
}

(c) 2013 Sunitha TH et al. This is an open-access article distributed under the terms of the Creative Commons Attribution License, which permits unrestricted use, distribution, and reproduction in any medium, provided the original work is properly cited.

\begin{abstract}
It's a cross sectional observational study conducted in outpatient clinic of OBG, SDMCMS\&H, Dharwad between July-December 2012. 200 married women between 20-45 yrs were interviewed with predesigned questionnaire. Effort was made to identify reasons for wide gap between knowledge and practice of contraception. All women knew atleast one method of contraception but $48 \%$ were using some sort of contraception. Most known method was female sterilization, least known were injectables and male sterilization. Common method chosen was female sterilization (70.8\%). None adopted male sterilization. Reasons for not using contraception were desire to have child $(25 \%)$, desire for boys $(13.4 \%)$, worried about side effect $(16.3 \%)$, opposition from family members $(11.5 \%)$, felt pregnancy was naturally spaced $(11.5 \%)$, no specific reasons $(10.5 \%)$, couldn't avail contraceptive facilities $(5.7 \%)$, inconvenient to use $(5.7 \%)$. Educational and motivational activities from doctors and health workers is needed to promote the use of contraception.
\end{abstract}

Keywords: Knowledge, Attitude, Practice, Contraception, Population

\section{INTRODUCTION}

India is the second most populous country in the world having a rapidly growing population which is currently increasing at the rate of 16 million each year. ${ }^{1}$ In the early 1950 's the Government of India launched a family welfare programme, whose main objective was to spread the knowledge of family planning methods and to develop an attitude favorable for adoption of contraceptive methods. The National population policy was revised by Government of India in 2000, to slow down the growth rate.

Despite constant efforts by the government, the unmet needs of contraception still remain. The reasons for these unmet needs have to be studied in detail for better understanding of the situation and to help the Government. in formulation of appropriate policies and approaches.
This study was carried out to assess the knowledge, attitude and practice of contraceptive methods among women attending a tertiary hospital. An effort was made to identify the reasons for not using contraceptive methods and thus know the reasons affecting the outcome of the family planning programme in this part of North Karnataka.

\section{METHODS}

This observational study was conducted in the outpatient clinic of OBG department of Sri Dharmasthala Manjunatheshwara College of Medical Sciences and Hospital, Sattur, Dharwad between July 2012 December 2012. 200 married women between the age group of 20-45 yrs were interviewed with the help of a predesigned questionnaire. 
The questionnaire elicited information regarding their age parity, educational status, knowledge, attitude and practice of contraception.

\section{RESULTS}

The Socio - demographic characteristics are shown in Table 1. About $40 \%$ of women were between the age group of 20-25 yrs. $35.5 \%$ of women had parity of more than two. $93.5 \%$ of women were literate. $44.5 \%$ of women had at least primary education. Table 2 Shows the spectrum of knowledge \& awareness of contraception.

All the women interviewed knew atleast one method of contraception including women from rural area. The best known method was the female sterilization $41.6 \%$ of rural women in the study knew about barrier method of contraception, while all the women from the urban area knew about condoms. Injectable contraceptives and male sterilization were the two less known methods, $30 \%$ and $45 \%$ respectively in the present study.

Knowledge about IUCD was $100 \%$ among the urban women while $58.3 \%$ of rural women knew about IUCD. Improving access to family planning (FP) services in the rural setup will help to increase both awareness and practice of contraception in the rural women. Friends and relatives were the main sources $(42 \%)$ of information.

$48 \%$ of women in our study were using any one form of contraception, while $52 \%$ were not using any method of contraception. Contraception usage was higher in the urban women $(62.5 \%)$ and less in the rural women (37.5\%).

The most common method chosen was female sterilization followed by IUCD (10.4\%). Among the 120 rural women interviewed, 30 of them had never used any contraception i.e. $25 \%$.

The most common reason quoted for not using any contraception was desire to have a child i.e. $25 \% .13 .4 \%$ of women in the study wanted to have male child. $16.3 \%$ of women were worried about side effects. $11.5 \%$ of women felt pregnancies were naturally spaced and there was no need to use any contraception. $11.5 \%$ of women had opposition from family members. $94 \%$ of them approved the usage of contraception. It is interesting to note that $42 \%$ of women interviewed felt there must be a male child in the family, which was one of the reasons for not using contraception. About $58.3 \%$ of women felt male child was a must to continue the family name and $41.6 \%$ of women felt it was to look after parents in old age.

Table 1: Socio demographic characteristics.

\begin{tabular}{|lll|}
\hline Characteristics & $\mathbf{n = 2 0 0}$ & $\%$ \\
\hline Age in years & & \\
\hline $20-25$ & 80 & 40 \\
\hline $26-30$ & 68 & 34 \\
\hline $35-40$ & 18 & 09 \\
\hline $41-45$ & 04 & 02 \\
\hline Parity & & \\
\hline P0 & 18 & 09 \\
\hline P1 & 30 & 15 \\
\hline P2 & 73 & 31.5 \\
\hline$>$ P2 & 79 & 35.5 \\
\hline Educational status & & \\
\hline Illiterate & 11 & 6.5 \\
\hline Primary & 89 & 44.5 \\
\hline Secondary & 80 & 40 \\
\hline University & 20 & 10 \\
\hline Occupation & & \\
\hline House wives/Home makers & 122 & 61 \\
\hline Farmers & 60 & 30 \\
\hline Govt. Services & 08 & 04 \\
\hline Business & 10 & 05 \\
\hline Economic Status & & \\
\hline Upper class & 12 & 06 \\
\hline Middle class & 128 & 64 \\
\hline Lower class & 60 & 30 \\
\hline Locality & & \\
\hline Urban & 120 & 60 \\
\hline Rural & & \\
\hline & & \\
\hline & & \\
\hline & & \\
\hline & & \\
\hline & & \\
\hline & & \\
\hline
\end{tabular}

Table 2: Spectrum of knowledge and awareness of contraception.

\begin{tabular}{|llllll|}
\hline \multirow{2}{*}{ Methods } & Urban & \multicolumn{5}{c|}{ Rural } & Total (\%) \\
\hline Any method & $\mathbf{n}(\mathbf{8 0})$ & $(\boldsymbol{\%})$ & $\mathbf{n}(\mathbf{1 2 0})$ & $\mathbf{( \% )}$ & \\
\hline Natural & 80 & 100 & 120 & 100 & 100 \\
\hline Pills & 55 & 68.75 & 40 & 33.3 & 47.5 \\
\hline IUCD & 80 & 100 & 54 & 45 & 67 \\
\hline Condoms & 80 & 100 & 70 & 58.3 & 75 \\
\hline Female sterilization & 80 & 100 & 50 & 41.6 & 65 \\
\hline Male sterilization & 80 & 100 & 120 & 100 & 100 \\
\hline Injectable contraceptives & 50 & 62.5 & 40 & 33.3 & 45 \\
\hline
\end{tabular}


Table 3: Sources of information.

\begin{tabular}{|lll|}
\hline 1) Public Medical sectors & $\mathbf{n ( 2 0 0 )}$ & $\%$ \\
\hline 2) Private Medical sectors & 30 & 25 \\
\hline 3) NGO/Trust & 34 & 17 \\
\hline 4) TV, Radio, Newspapers & 30 & 01 \\
\hline 5) Friends, relatives & 84 & 15 \\
\hline
\end{tabular}

Table 5: Contraceptive methods ever used.

\begin{tabular}{|lll|}
\hline Female sterilization & $\begin{array}{l}\text { Urban } \\
\mathbf{n ( 8 0 )}\end{array}$ & $\begin{array}{l}\text { Rural } \\
\mathbf{n ( 1 2 0 )}\end{array}$ \\
\hline Male sterilization & 32 & 36 \\
\hline Pills & 00 & 00 \\
\hline Condoms & 10 & 06 \\
\hline Natural & 04 & 10 \\
\hline Injectable contraception & 06 & 04 \\
\hline IUCD & 04 & 00 \\
\hline Not used any method & 12 & 24 \\
\hline
\end{tabular}

Table 4: Contraceptive methods currently in use.

\begin{tabular}{|llllll|} 
& Urban & \multicolumn{2}{c}{ Rural } & Total $(\%)$ \\
\cline { 2 - 5 } & $\mathbf{N}$ & $\%$ & $\mathbf{N}$ & $\%$ & 48 \\
\hline Current contraceptive users & 50 & 62.5 & 46 & 37.5 & 52 \\
\hline Not using any contraception & 30 & 37.5 & 74 & 61.6 & 70.8 \\
\hline Female sterilization & 32 & 64 & 36 & 78.2 & 0 \\
\hline Male Sterilization & 0 & 0 & 0 & 0 & 10.4 \\
\hline IUCD & 6 & 12 & 04 & 8.6 & 06.2 \\
\hline Pills & 4 & 08 & 02 & 5.6 & 08.3 \\
\hline Condoms & 4 & 08 & 04 & 8.6 & 04 \\
\hline Natural & 2 & 04 & -- & -- & 04 \\
\hline Injectable contraceptives & 2 & 04 & -- & -- & \\
\hline
\end{tabular}

Table 6: Reasons for not using contraception.

\begin{tabular}{|c|c|c|c|c|c|}
\hline & \multicolumn{2}{|c|}{ Urban } & \multicolumn{2}{|l|}{ Rural } & \multirow{2}{*}{ Total $(\%)$} \\
\hline & $n(30)$ & $\%$ & $\mathrm{n}(74)$ & $\%$ & \\
\hline 1) Worried about side effects & 5 & 16.6 & 12 & 16.2 & 16.3 \\
\hline 2) No specific reasons & 2 & 06.6 & 09 & 12.1 & 10.5 \\
\hline $\begin{array}{l}\text { 3) Opposition from family members / } \\
\text { husband }\end{array}$ & 1 & 3.3 & 11 & 14.8 & 11.5 \\
\hline 4) Wanted to have a child & 11 & 36.6 & 15 & 20.2 & 25 \\
\hline $\begin{array}{l}\text { 5) Could not access family planning } \\
\text { services }\end{array}$ & 01 & 3.3 & 05 & 06.7 & 5.7 \\
\hline 6) Felt pregnancy was naturally spaced & 02 & 6.6 & 10 & 33.3 & 11.5 \\
\hline 7) Wants to have male child & 06 & 20 & 08 & 10.8 & 13.4 \\
\hline 8) Inconvenient, lack of privacy & 02 & 6.6 & 04 & 05.4 & 05.7 \\
\hline
\end{tabular}

Table 7: Attitude towards family planning.

\begin{tabular}{|lllll|}
\hline \multirow{2}{*}{ Users } & \multicolumn{2}{l}{ Non users } & Total \\
\cline { 2 - 5 } & $\mathbf{n}(\mathbf{9 6})$ & $\mathbf{n ( 1 0 4 )}$ & $\mathbf{n ( 2 0 0 )}$ & $(\%)$ \\
\hline Approval & 96 & 92 & 188 & 94 \\
\hline Disapproval & 0 & 12 & 12 & 06 \\
\hline
\end{tabular}

\section{DISCUSSION}

The increasing growth of population has become an urgent global problem. The current trends in family planning (FP) in India show high level of knowledge of contraceptives among eligible couples yet the acceptance remains low especially for spacing methods. 
Table 8: View on contraception.

\begin{tabular}{|c|c|c|c|}
\hline & $\begin{array}{l}\text { Urban } \\
\text { n(80) }\end{array}$ & $\begin{array}{l}\text { Rural } \\
\mathrm{n}(\mathbf{1 2 0})\end{array}$ & $\begin{array}{l}\text { Total } \\
(\%)\end{array}$ \\
\hline \multicolumn{4}{|l|}{$\begin{array}{l}\text { 1) Reasons for using } \\
\text { Contraception }\end{array}$} \\
\hline a) Economic reasons & 40 & 48 & $44 \%$ \\
\hline b) Motivation & 18 & 26 & $22 \%$ \\
\hline c) Small family norm & 10 & 14 & $12 \%$ \\
\hline d) Incentives & 12 & 32 & $22 \%$ \\
\hline \multicolumn{4}{|l|}{ 2) Who decides? } \\
\hline $\begin{array}{l}\text { a) Mother in law } \\
\text { decides }\end{array}$ & 12 & 36 & $24 \%$ \\
\hline b) Husband decides & 24 & 44 & $34 \%$ \\
\hline c) Wife decides & 08 & 10 & $09 \%$ \\
\hline d) Both decides & 36 & 20 & $28 \%$ \\
\hline \multicolumn{4}{|l|}{$\begin{array}{l}\text { 3) Quality of existing } \\
\text { FP services }\end{array}$} \\
\hline \multicolumn{4}{|l|}{$\begin{array}{l}\text { a) Satisfied with FP } \\
\text { services }\end{array}$} \\
\hline at PHC/Govt hospitals & 34 & 44 & $39 \%$ \\
\hline \multicolumn{4}{|l|}{$\begin{array}{l}\text { b) Satisfied with FP } \\
\text { services at }\end{array}$} \\
\hline private hospitals & 64 & 60 & $62 \%$ \\
\hline \multicolumn{4}{|l|}{ 4) Ideal no of children } \\
\hline 1 & 08 & 10 & $09 \%$ \\
\hline 2 & 58 & 80 & $69 \%$ \\
\hline$>2$ & 14 & 30 & $22 \%$ \\
\hline \multicolumn{4}{|l|}{$\begin{array}{l}\text { 5) Desire for male } \\
\text { offspring }\end{array}$} \\
\hline $\begin{array}{l}\text { a) It is a must that } \\
\text { there should be a }\end{array}$ & 30 & 54 & $42 \%$ \\
\hline \multicolumn{4}{|l|}{ male child } \\
\hline \multicolumn{4}{|l|}{ b) Why? } \\
\hline $\begin{array}{l}\text { i) To continue the } \\
\text { family name }\end{array}$ & 17 & 32 & $58.3 \%$ \\
\hline $\begin{array}{l}\text { ii) To look after } \\
\text { parents in old age }\end{array}$ & 13 & 22 & $41.6 \%$ \\
\hline
\end{tabular}

The present study aimed to assess the knowledge, attitude and practice of FP methods among women attending tertiary hospital which caters to both urban and rural women.

Results showed that all the women including women from rural areas knew at least one method of contraception $(100 \%)$. In a similar Indian study, the awareness rate was $(82.2 \%){ }^{2}$ Women's education play an important role in increasing the awareness. In the present study $93.5 \%$ were literate. Only $6.5 \%$ were illiterate. Another factor responsible for knowledge of FP methods is exposure of messages through mass media. Though knowledge of contraception was $100 \%$, only $48 \%$ of women were actually using any one method of contraception.

The current unmet need for FP is about $15.8 \%$, of which the need for spacing is about $8.3 \%$ and for limiting births is $7.5 \%$, which needs to be met through programmatic interventions. Contraceptive usage was higher in the urban women $(62.5 \%)$ and less in rural women $(38.5 \%)$. This is similar to the data obtained by NFHS-2 (National Family Health Survey) which shows 58\% among the urban population and $45 \%$ among rural women. Female sterilization was adopted by $70.8 \%$ of women in the present study. According to NFHS-2, female sterilization was the most prevalent method of contraception $(71 \%)$ and most PHC were not adequately staffed. Only $16 \%$ of PHC had physicians trained in conducting sterilization and only $1 / 3^{\text {rd }}$ had atleast one paramedical staff trained in IUCD insertion. ${ }^{3}$

$52 \%$ of women interviewed were not using any method of contraception. Two Indian studies showed similar results, $55 \%$ and $46 \%$ of non users. ${ }^{4}$ While general level of approval for contraception was high (94\%), the practice level was only $48 \%$. KAP survey conducted among rural people in UP, revealed high level of approval for contraception but the practice level was very low, 14\%. ${ }^{5}$ Constant motivation by doctors and health workers and by improving the FP services at both government \& private health sectors, the gap between knowledge, attitude and practice can be minimized. Only $39 \%$ of women were satisfied with the existing FP services at PHC/Government hospitals and only $62 \%$ of them were satisfied with private hospitals.

Both Government and Private hospitals should provide appropriate information, clear doubts about the misconceptions and worries about side effects and should highlight the benefits of the various contraceptive methods at every visit to the hospital. About $16.3 \%$ of women not using contraception were worried about side effects of contraceptive methods. Every postpartum women must receive adequate FP advises during their postnatal follow-ups.

In order to reduce the gap between knowledge, attitude and practice of contraception, one of the most important factor is regular availability of contraceptives and good quality of family planning services both at Government and Private medical sectors.

Alternative methods of contraception must be informed and offered so that the rate of continuation of contraception will improve. Constant motivation and FP advice by both doctors and health workers will play a great role in decreasing the unmet need of contraception.

\section{CONCLUSION}

This study reveals good knowledge and favorable attitude of women towards contraception. But there are various reasons for the non acceptance of contraceptives like worries about side effects, misconceptions, preference for male child, and poor FP services. Thus by proper motivation, counseling and improving facilities at both 
Government \& Private sector, the unmet need of contraception can be achieved.

Funding: No funding sources

Competing interests: None declared

Ethical approval: Not required

\section{REFERENCES}

1. Govt. of India (2001). Census of India 2001, Provisional Population Totals, paper-1 of 2001.

2. Srivastava R, Srivastava D.K. Jina R. Srivastava K, Sharma N, Sana S. Contraceptive Knowledge, attitude and practice (KAP survey). J Obstet Gynecol India 2005;55:546-50.

3. United Nation Population Fund- India, Ministry of Health and Family planning, Government of India: Contraceptive Updates, Oct 2005.

4. Pranchi R, Das G.S Ankur B, Shipra J, Benitak A Study of Knowledge, attitude and practice of family planning among the women reproductive age group in Sikkim, J. Obstet Gynecol India 2003;58:63-7.

5. Misra GD, Ashraf A, Simmons GB, Simmons R, ed. Organization for change: a systems analysis of family planning in rural India. New Delhi, Radiant Publishers; 1981:155-80.

DOI: $10.5455 / 2320-1770 . i j r \operatorname{cog} 20130612$

Cite this article as: Sunita TH, Desai RM.

Knowledge, attitude and practice of contraception among women attending a tertiary care hospital in India. Int J Reprod Contracept Obstet Gynecol 2013;2:172-6. 